\title{
Assessment of Organizational Culture of Selected Construction Companies in Nigeria
}

\author{
Awolesi, J.A.B ${ }^{1}$ and Dr. Fabi, J. K ${ }^{2}$ \\ ${ }^{1-2}$ Department of Quantity Surveying \\ School of Environmental Studies \\ The Federal Polytechnic, Ilaro \\ Ogun State
}

Nigeria

\begin{abstract}
Organization culture is a concept that has been given little attention in the construction industry compare to other industries. Organization culture has a significant impact on the performance of any organization and its importance cannot be overemphasized. This paper aims at identifying the critical factors for constructing organizational culture profile and to compare the prevalent culture of construction organizations with respect to the Competing Value Framework (CVF). To achieve the main objective of this paper, eighty-one (81) questionnaires were administered on experts from selected major construction companies in Nigeria. The population of the study comprises of engineers, architects, quantity surveyors and builders, who were selected using random sampling technique. The results of the analysis revealed that there are varying ratings for each of the organizations with respect to critical factors for constructing. The overall ratings indicated that the most critical factor for constructing organization culture is the fact that the organization must be highly organized (4.23), the organization must be result-oriented (4.20) and teamwork should be the focus of the employee (4.14). For prevalent organization culture assessment, the results also indicated varying ratings for all the three organizations involved in the study. The most significant factor is the organizations' commitment to innovation and development (4.32), aggressive, results-oriented focus (4.28) and characterized by teamwork, consensus, and participation (4.27). The high mean scores obtained in the study showed that construction companies have a culture in place in their organizations. The results further affirm the position of the three construction companies as leading light for others in the Nigerian construction industry.
\end{abstract}

Key Words: Organization Culture, Construction Industry, Assessment.

\section{INTRODUCTION}

Globally, construction sector is a basic industry on which the development of a country depends. This assertion is true when a critical look is given to the contribution of the sector to the nation's economy. The main three parties in a construction project are the Employer, the Consultant and the Contractor whose mutual responsibilities are defined by contractual and professional obligations. [1] posited that the quality of infrastructure and construction projects of a country play a significant role in its growth and development. Performance evaluation in construction project generally focuses on a limited number of performance elements which is the act of fulfilling the project goals related to the product, which are; completing the project on time, within budget and with the required quality and to client satisfaction. Therefore, for construction clients and end users of completed facilities to realize best value, the concept of organisational culture must be critically evaluated in the industry to improve the quality of product and services [2]. In the past, researchers have focused on the performance of the industry, especially building projects without recourse to the organisation responsible for the projects. Many have therefore called for a critical consideration of the culture within the construction organisation handling construction projects to enhance efficient project delivery in construction[3]

Furthermore, the success or failure of any firm depends on the culture imbibed by the organization. Each company has an organizational culture, and depending on its strength, the organisational culture may have a prominent impact on the members of 
organization, their values and behaviour. [4] posited that organizations can be flexible or stagnant, innovative or conservative, focusing on their external or internal environment. Making research in the organisations, scientists have realized recently the important role of organisational culture in the lives of organization members and in general the contribution of organisational culture into the company's successful performance [4]. The absence of a well laid down culture in most construction firms to some extent may affect the level of commitment of employees negatively and the productivity of such company [5]. Quality and efficiency have been identified as the major imperatives lacking in Nigeria's construction industry [6]. From a general knowledge, few construction firms in Nigeria under-pay their workers. With this poor salary package, "quality might never be ingrained in culture". As a result of poor salary package, the focus of labours tends to be the quantity of work done rather than the quality of work executed [7]. In this regard, all stakeholders involved in construction projects have a role to play in order to deliver a quality product.

Also, conflicts between project participants have been identified in various construction industries to be one of the principal causes of poor performance on construction projects. These conflicts occur at the interface because participants have different objectives and different organisational cultures which define their approach to work and relationship with other project participants [8]. On this note, this study sets out to assess critical factors for constructing the organization profile and to compare the prevalent culture of construction firms with respect to the competing value framework (CVF).

\section{LITERATURE REVIEW}

The construction industry is dynamic and fragmented, and stakeholders are constantly confronted with new organizations in a changing environment. Understanding their organizational culture will enable firms to better manage their organization and prevent misunderstanding and conflict often due to cultural difference. This could further enhance performance, quality and ensuring their long-term success.

\subsection{Organizational Culture}

Xiaoming and Junchen (2012) and O'Donnell and Boyle (2008) have emphatically stated that, there is no agreement on universally accepted definition as far as organisational culture is concerned. Over 1000 definitions of culture exist in literature. Many definitions have emerged over time, which the researcher thinks relate to the context in which the various authors referred as culture, because definitions in cultural studies relate to the perspective adapted. [11] emphasized that, managers acknowledge and understand the presence of culture in their organisations.

[8] posited that, in any organisation there is an established bond among employees and their organisation in totality and patterns which dictates the behaviours of them, understanding the WHY's and HOW's exposes one to the culture of the organisation. [10] opined that Organisational Culture exists as a result of the background meaning the organisation experiences in the past sprouting from the accepted norms of doing business. Organisational Culture according to [12] is also influenced by the external environment to fine-tune its belief as well as internal structures of the organisation. Implying that, the external factors result in the ability of the company to adapt to the beliefs of the external environment. Schein (2003) also advised that the genesis of Organisation Culture is embedded in leaders, because they transfer their belief in the execution of their duties.

Oney-Yazici, Giritli, Topcu-Oraz and Acar (2007) defined organisational culture as the "shared assumptions, beliefs and normal behaviours (norms) present in an organisation". Organisational Culture was described by [15] as the corporate belief of the individuals within an institution as well as their understanding on their belief. [13] defined Organisational Culture as "a pattern of shared basic assumptions that was learned by a group as it solved its problems of external adaptation and internal integration, that has worked well enough to be considered valid and, therefore, to be taught to new members as the correct way to perceive, think, and feel in relation to those problems".

Rameezden and Gunarathna (2003) simplified the definition of organisational culture as the push and pull factors that are acknowledged to be influential and essential in an organisation. [13] definitions backed up [17] who asserted that, organisational culture is a learning or continual process which can be learnt by new members of a group and emanates from the history or traditions of an organisation.

\subsection{Determinant of Organizational Culture}

Rameezden and Gunarathna (2003) and Fellow and Liu (2013) believe that the foundation of Organisational Culture emanates from National Culture and notwithstanding that, discovered problem solving techniques contribute to the realization of the Culture of an Organisation. Conversely, [19] opined that, the individual beliefs of the employees in an organisation defined the Organisational Culture. [12] asserted that, Organisational Culture is synonymous to the real self of an individual, which underpins the reason why Culture defers from one organisation to the other because every individual is unique. [10] recommended that, the success story achieved by the organisation in solving its problems and what the organisation is capable should be used to define the culture of the organisation. 
Campbell, Stonehouse and Houston (2002) concluded that, the following factors contribute to the determination of culture in organisations:

1. The philosophy of the organisation's founder

2. The business activities undertaken by the organisation

3. The relationships established in the work environment

4. The management and control systems used in the organisation.

5. The influence of National culture

6. The organisational structure, and

7. Technological advancement of the organisation

Schein (2003) asserted that, the founders' belief and a workable philosophy form the basis of culture. [21] also related Organisational Culture as the elements that inform the decision of a leader of an organisation. [22] posited that, it is the need of every individual to be recognized with a particular social identity and such is realized as a result of the culture of an organisation. The well-being, performance, effectiveness and efficiency of an organisation are recognized based on the integral role of organisational culture.

Abu-Jarad, Yusof and Nikbin (2010) posited that the performance of an organisation can never be separated from its culture. [13] asserted that, the stability and effectiveness of an organisation is entirely linked to its culture and the basic utmost thing that keeps an organisation to function efficiently and effectively is Organisational Culture. [14] added that, though there is ambiguity on the definition of culture, but it is accepted among researchers that, culture is an indication of the beliefs and shared assumptions of a group.

Drawing from earlier researchers, the formation of culture in an organisation does not occur instantaneously but developed with time. Organisations are product of the society; thereby culture of the organisation is a prototype of the national culture of the organisational founders [23]. Furthermore, the formulated visions become the core belief of the organisation which is the first level of culture according to [13].

\subsection{Importance of Culture to the Organization}

Culture has penetrated through the organisational studies. Culture studies have gained root within the last three decades and continues to make strides in management studies. The remarkable idea about the concept of culture is its indelible contribution to the well-being of organisations. From a lay person point of view culture is said to give a group of people an identity which is not technically different from [10] view regarding the importance of culture to the organisation. Besides, realization of culture and its typologies informs management to be circumspect since every style adapted in the day-to-day running of the organisation corresponds to different expectations. [14] added that, culture is not only instrumental to the effectiveness of the organisation in the short-term but the long-term as well. [21]proposed that, even partnership between organisations yields good outcome provided the entities involve have similar organisational culture.

Furthermore, Organisational culture brings about internal integration and coordination. It defines amongst other things like mode of communication, attitudes, beliefs, values and goals. It also enhances the success of major initiatives such as mergers, reorganisations, attitude change programmes and Total Quality Management (TQM) [24, 25]. Organisational culture also determines the level of maturity of the business of the organisation [6]. It can equally be used to enhance improvement to organisational effectiveness. In terms of performance, culture could enhance the level of employees' commitment and it is a key to the success of an organisation. But certain types of culture could enhance performance than others. Companies which put emphasis in key managerial components, such as customers, stakeholders, employees and leadership, outperform those that do not have these cultural traits. This is true when the right type of commitment of the employees is cultivated through the satisfaction of the employees. Without commitment, organisational culture alone cannot significantly enhance performance. In other words performance is enhanced when the type of organisational culture in practice is compatible with the type of employee commitment. Hence employee commitment is an essential ingredient for ensuring the successful implementation of the organisational policies and plans and thereby enhancing performance [23].

Hoonakker (2006) further stated that clients demand improved service quality, faster buildings and innovations in technology. Improving quality of construction is the easiest way to improve the industry. Culture is a complex issue that essentially includes all of a group's shared values, attitudes, beliefs, assumptions, artefacts, and behaviours, to the extent that members are not even aware they are influenced by it [27]. According to [28], being shared means that it is a social phenomenon that is learned and involves arbitrarily assigned, symbolic meanings. In this regard, culture is ingrained in believes and values. Typically, the construction industry has a culture, that is, shared understandings about what is expected, by all participants, in the way relationships are conducted between participants in the construction process. It is not only the final product that is subject to 
criticisms but the processes, the parties, the materials etc., are under tremendous pressure for better quality in construction [29, 30]. Failure of any of the parties will seriously affect the quality of the final project. The construction industry tends to define quality as the ability of products and processes to conform to the established requirements and specifications [29]. Quality is a persuasive concern throughout the entire construction project process, as the performance of each phase in the process will affect the performance of next phase [30]. Quality may perhaps serve as a measure of client satisfaction, project and contractor's performance. Contractors often perceive total quality management as an extra cost, but they do not realize that it is not the quality that costs but rather the non-conformance to quality that is expensive [31]. Xiaoming and Junchen (2012), O'Donnell and Boyle (2008) and Sodangi et al. (2004) posited that a strong quality culture continuously delivers high quality products and services are an important prerequisite to sustained competitive advantage. Hence, rather than understanding culture and quality as independent entities, it is important to understand that quality actually stems from a broader cultural perspective [28].

\section{METHODOLOGY}

The purpose of this quantitative study is to assess the critical factors for construction organization culture and to compare prevalent organization culture of selected major construction companies in Nigeria. The study adopts questionnaire survey method. This study began with an extensive review of related studies organization culture in diverse fields before streamlining to the construction industry to establish a list of factors related to this study. The reported list was further reviewed in a pilot survey before finally administered on the respondents. The population for this study includes experts in major construction industry comprising engineers, architects, quantity surveyors and builders. Out of 100 questionnaires administered to respondents, responses were received from 81 experts with varied interest and/or experience and the survey was administered between March and August 2019. 81 questionnaires were valid and used for the analysis. A 5-point Likert scale on the level of agreement on the identified impediments was used in the study. 1- strongly disagree, 2- disagree, 3-somewhat agree, 4- agree, and 5-strongly agree. Data were collected personally by the researchers through a cross-sectional survey using random sampling. The data collected was analysed using SPSS 22 version. Mean score (MS) was used for the descriptive statistics. Mean score is widely used in construction management research. Mean score is used to conduct evaluation from the survey results. Thus, the relative rankings of the variables /factors were determined from the survey results using the measurement scales.

\section{RESULTS}

\subsection{Demographic details of the respondents}

The demographic details of the respondents. $11 \%$ of the respondents are HND holders, $57 \%$ are BSc holders while $32 \%$ are MSc/MBA holders. $86 \%$ of the respondents are corporate members of their respective professional bodies. The respondents are all working in contracting organizations. All the respondents have over twelve years' experience in the Nigerian construction industry. Over $60 \%$ of the respondents have handled five projects and above. This shows that the information supplied by the respondents can be considered appropriate and adequate for the study.

\subsection{Discussion of Findings}

There are thirty-three factors which were identified from existing typologies and organisational theories through critical review of literature. The pilot study carried out and suggestions from the industry practitioners gave rise to the use of all the thirty-three factors which were used for the study. Table 1 shows the ranks of various critical factors for constructing an organizational culture model. From the analysis, it was discovered that the three construction companies namely Julius Berger Plc (JB), Reynolds construction company (RCC) and China Construction Company (CCC), have different ratings for the variables assessed in this research. For Julius Berger, the most critical factor for constructing an organization culture is "sharing information freely" (4.36), this followed by "innovative thinking" (4.32) and "result oriented" (4.30). For Reynold Construction Company, the most critical factor in constructing organization culture is "teamwork" (4.38), this is followed by "sharing information freely" (4.37) and "highly organized (4.30). For China Construction Company, "accuracy" (4.44) is the most critical factor for constructing organization culture. This is followed by "highly organized" (4.41) and "coordination" (4.33). For the overall ratings by the three construction companies, the most critical factor is "highly organized" (4.23). This is followed by "result oriented" (4.20) and "teamwork" (4.14). All other factors have mean scores greater than 3.50 except "taking risk" (3.43) and "action oriented" (3.41). This result is high on a scale of 5. Ameyaw (2014) used similar scale i.e. $<1.50=$ very low, 1.50-2.49 = low, 2.50-3.49= moderate, $3.50-4.49=$ high and $\geq 4.50=$ very high. This indicates that they are all critical and must be given utmost attention in the construction industry. It also affirms the fact that there is need for internal supportiveness so as to maintain a competitive mode of operation in order to achieve an efficient outcome. The results further inform that, factors that tend to positively contribute to the organisations should be used for defining the culture of an organisation. This agrees with the study of Mahmood, (2006), Idrus and Khamidi (2014), and Ittner and Larcker (1998). 
Table 1 Critical factors for constructing an Organizational Culture Model

\begin{tabular}{|c|c|c|c|c|c|c|c|c|c|}
\hline \multirow[t]{2}{*}{$\mathbf{S} / \mathbf{N}$} & \multirow[t]{2}{*}{ Variables } & \multicolumn{2}{|c|}{$\begin{array}{c}\underset{\text { Julius Berger }}{(\mathbf{J B})} \\
\mathbf{N}=\mathbf{2 7}\end{array}$} & \multicolumn{2}{|c|}{$\begin{array}{l}\text { Reynolds } \\
\text { Construction } \\
\text { Company (RCC) } \\
\text { N=27 }\end{array}$} & \multicolumn{2}{|c|}{$\begin{array}{c}\text { China } \\
\text { Construction } \\
\text { Company } \\
\text { (CCC) } \mathrm{N}=27\end{array}$} & \multirow[t]{2}{*}{$\begin{array}{c}\text { Overall } \\
\text { Mean }\end{array}$} & \multirow[t]{2}{*}{$\begin{array}{c}\text { Overall } \\
\text { Ranking }\end{array}$} \\
\hline & & Mean & Rank & Mean & Rank & Mean & Rank & & \\
\hline 1 & Taking Risk & 3.53 & $32^{\text {nd }}$ & 3.26 & $33^{\text {rd }}$ & 3.51 & $30^{\text {th }}$ & 3.43 & $32^{\text {nd }}$ \\
\hline 2 & Innovative & 4.32 & $2^{\text {nd }}$ & 3.48 & $29^{\text {th }}$ & 3.78 & $23^{\text {rd }}$ & 3.86 & $19^{\text {th }}$ \\
\hline 3 & Rule Oriented & 3.74 & $21^{\mathrm{st}}$ & 3.30 & $30^{\text {th }}$ & 3.46 & $31^{\text {st }}$ & 3.50 & $31^{\mathrm{st}}$ \\
\hline 4 & Research \& Development & 3.93 & $12^{\text {th }}$ & 3.89 & $19^{\text {th }}$ & 3.44 & $32^{\text {nd }}$ & 3.75 & $28^{\text {th }}$ \\
\hline 5 & Utilize available opportunity & 3.78 & $19^{\text {th }}$ & 3.81 & $21^{\mathrm{st}}$ & 3.78 & $23^{\text {rd }}$ & 3.79 & $25^{\text {th }}$ \\
\hline 6 & Taking individual responsibility & 3.88 & $16^{\text {th }}$ & 3.81 & $21^{\mathrm{st}}$ & 4.33 & $3^{\text {rd }}$ & 4.01 & $13^{\text {th }}$ \\
\hline 7 & Stable in operation & 4.17 & $5^{\text {th }}$ & 3.28 & $31^{\mathrm{st}}$ & 4.00 & $16^{\text {th }}$ & 3.82 & $22^{\text {nd }}$ \\
\hline 8 & Job Security & 3.58 & $31^{\mathrm{st}}$ & 3.78 & $25^{\text {th }}$ & 3.93 & $19^{\text {th }}$ & 3.76 & $27^{\text {th }}$ \\
\hline 9 & Predictable & 3.52 & $33^{\text {rd }}$ & 3.70 & $26^{\text {th }}$ & 4.22 & $9^{\text {th }}$ & 3.81 & $23^{\text {rd }}$ \\
\hline 10 & Calm & 3.60 & $29^{\text {th }}$ & 3.81 & $21^{\mathrm{st}}$ & 3.89 & $20^{\text {th }}$ & 3.77 & $26^{\text {th }}$ \\
\hline 11 & Low Conflict & 3.97 & $11^{\text {th }}$ & 3.96 & $17^{\text {th }}$ & 4.22 & $9^{\text {th }}$ & 4.05 & $11^{\text {th }}$ \\
\hline 12 & $\begin{array}{l}\text { Management respect for } \\
\text { subordinates }\end{array}$ & 3.63 & $26^{\text {th }}$ & 3.70 & $26^{\text {th }}$ & 3.52 & $29^{\text {th }}$ & 3.62 & $30^{\text {th }}$ \\
\hline 13 & Fairness & 3.62 & $28^{\text {th }}$ & 4.00 & $13^{\text {th }}$ & 3.78 & $23^{\text {rd }}$ & 3.80 & $24^{\text {th }}$ \\
\hline 14 & Tolerance & 3.74 & $21^{\mathrm{st}}$ & 3.89 & $19^{\text {th }}$ & 3.59 & $27^{\text {th }}$ & 3.74 & $29^{\text {th }}$ \\
\hline 15 & $\begin{array}{l}\text { Opportunities for professional } \\
\text { growth }\end{array}$ & 4.11 & $7^{\text {th }}$ & 4.07 & $8^{\text {th }}$ & 3.86 & $22^{\text {nd }}$ & 4.01 & $13^{\text {th }}$ \\
\hline 16 & High pay for good performance & 3.67 & $25^{\text {th }}$ & 4.09 & $7^{\text {th }}$ & 3.78 & $23^{\text {rd }}$ & 3.85 & $21^{\mathrm{st}}$ \\
\hline 17 & Praise for good performance & 3.78 & $19^{\text {th }}$ & 3.93 & $18^{\text {th }}$ & 4.26 & $6^{\text {th }}$ & 3.99 & $15^{\text {th }}$ \\
\hline 18 & Action oriented & 3.63 & $26^{\text {th }}$ & 3.26 & $31^{\mathrm{st}}$ & 3.33 & $33^{\text {rd }}$ & 3.41 & $33^{\text {rd }}$ \\
\hline 19 & Results oriented & 4.30 & $3^{\text {rd }}$ & 4.04 & $10^{\text {th }}$ & 4.26 & $6^{\text {th }}$ & 4.20 & $2^{\text {nd }}$ \\
\hline 20 & High expectation for performance & 4.28 & $4^{\text {th }}$ & 3.89 & $19^{\text {th }}$ & 4.22 & $9^{\text {th }}$ & 4.13 & $4^{\text {th }}$ \\
\hline 21 & Enthusiasm for the job & 3.59 & $30^{\text {th }}$ & 4.03 & $12^{\text {th }}$ & 4.19 & $13^{\text {th }}$ & 3.94 & $17^{\text {th }}$ \\
\hline 22 & Highly organized & 3.98 & $10^{\text {th }}$ & 4.30 & $3^{\text {rd }}$ & 4.41 & $2^{\text {nd }}$ & 4.23 & $1^{\mathrm{st}}$ \\
\hline 23 & Analytically minded & 3.69 & $24^{\text {th }}$ & 3.99 & $14^{\text {th }}$ & 3.98 & $18^{\text {th }}$ & 3.89 & $18^{\text {th }}$ \\
\hline 24 & Precision & 3.70 & $23^{\text {rd }}$ & 4.26 & $4^{\text {th }}$ & 4.33 & $3^{\text {rd }}$ & 4.10 & $8^{\text {th }}$ \\
\hline 25 & Accuracy & 3.79 & $18^{\text {th }}$ & 4.15 & $5^{\text {th }}$ & 4.44 & $1^{\mathrm{st}}$ & 4.13 & $4^{\text {th }}$ \\
\hline 26 & Meticulous & 3.89 & $14^{\text {th }}$ & 4.15 & $5^{\text {th }}$ & 4.19 & $13^{\text {th }}$ & 4.08 & $10^{\text {th }}$ \\
\hline 27 & Collaboration & 4.05 & $8^{\text {th }}$ & 3.97 & $15^{\text {th }}$ & 3.89 & $20^{\text {th }}$ & 3.97 & $16^{\text {th }}$ \\
\hline 28 & Teamwork & 3.81 & $17^{\text {th }}$ & 4.38 & $1^{\mathrm{st}}$ & 4.22 & $9^{\text {th }}$ & 4.14 & $3^{\text {rd }}$ \\
\hline 29 & People oriented & 3.90 & $13^{\text {th }}$ & 3.67 & $28^{\text {th }}$ & 4.00 & $16^{\text {th }}$ & 3.86 & $19^{\text {th }}$ \\
\hline 30 & Sharing information freely & 4.36 & $1^{\mathrm{st}}$ & 4.37 & $2^{\text {nd }}$ & 3.59 & $27^{\text {th }}$ & 4.11 & $6^{\text {th }}$ \\
\hline 31 & Coordination & 4.14 & $6^{\text {th }}$ & 3.81 & $21^{\mathrm{st}}$ & 4.33 & $3^{\text {rd }}$ & 4.09 & $9^{\text {th }}$ \\
\hline 32 & Enabling working environment & 4.02 & $9^{\text {th }}$ & 4.04 & $10^{\text {th }}$ & 4.26 & $6^{\text {th }}$ & 4.11 & $6^{\text {th }}$ \\
\hline 33 & Mutual responsibility & 3.89 & $14^{\text {th }}$ & 4.07 & $8^{\text {th }}$ & 4.11 & $15^{\text {th }}$ & 4.02 & $12^{\text {th }}$ \\
\hline
\end{tabular}

Table 2 shows the prevalent organization culture assessment instrument (OCAI). For Julius Berger, the study revealed that "The leadership in this firm is generally considered to exemplify coordinating, organizing, or smooth-running efficiency" (4.38) is the most rated dimension. This is followed by "The glue that holds this firm together is commitment to innovation and development. There is an emphasis on being on the cutting edge" (4.31) and "The glue that holds this firm together is formal rules and policies. Maintaining a smooth-running organization is important (4.30). For Reynold Construction Company, the study also revealed that "the glue that holds this firm together is commitment to innovation and development. There is an emphasis on being on the cutting edge" (4.31) is the most rated dimension. This is followed by "The leadership in this firm is generally considered to exemplify coordinating, organizing, or smooth-running efficiency" (4.30) and "The leadership in this firm is generally considered to exemplify a no-nonsense, aggressive, results-oriented focus" (4.26). For the China Construction Company, the most rated dimension is "The leadership in this firm is generally considered to exemplify coordinating, organizing, or smooth-running efficiency" (4.36). This is followed by "The leadership in this firm is generally considered to exemplify a no-nonsense, aggressive, results-oriented focus" (4.30) and "The glue that holds this firm together is commitment to innovation and development. There is an emphasis on being on the cutting edge" (4.29). On the overall level, "The glue that holds this firm together is commitment to innovation and development. There is an emphasis on being on the cutting edge" (4.32) is the most rated dimension by all the construction companies. This is followed by "The leadership in this firm is generally considered to 
exemplify a no-nonsense, aggressive, results-oriented focus" (4.28) and "The management style in this firm is characterized by teamwork, consensus, and participation" (4.27). All other dimensions as rated by the respondents have mean scores greater than 3.50. This result is high on a scale of 5. Ameyaw (2014) used similar scale i.e. $<1.50=$ very low, $1.50-2.49=10 w, 2.50-3.49=$ moderate, $3.50-4.49=$ high and $\geq 4.50=$ very high. This agrees with the study of Hofstede, (2011), Drew, (1997) and Mc Auley (2007).

Table 2 Prevalent Organizational Culture Assessment Instrument (OCAI) Dimension

\begin{tabular}{|c|c|c|c|c|c|c|c|c|c|}
\hline $\mathbf{S} / \mathbf{N}$ & Variable & $\begin{array}{r}\text { Julius } \\
\mathbf{N}\end{array}$ & erger & $\begin{array}{r}\mathbf{R} \\
\mathrm{Co} \\
\mathrm{Com}\end{array}$ & $\begin{array}{l}\text { lolds } \\
\text { uction } \\
\text { y (RCC) } \\
27\end{array}$ & $\begin{array}{r}\text { Con } \\
\text { Comp }\end{array}$ & $\begin{array}{l}\text { ina } \\
\text { ruction } \\
\text { y }(\mathrm{CCC}) \\
=27\end{array}$ & $\begin{array}{l}\text { Over } \\
\text { all } \\
\text { Mean }\end{array}$ & $\begin{array}{l}\text { Ove } \\
\text { rall } \\
\text { Ran } \\
\text { king }\end{array}$ \\
\hline & & Mean & Rank & Mean & Rank & Mean & Rank & & \\
\hline 1 & $\begin{array}{l}\text { This firm is a very personal place. It } \\
\text { is like a family. People seem to } \\
\text { share a lot of themselves }\end{array}$ & 3.81 & $15^{\text {th }}$ & 3.91 & $16^{\text {th }}$ & 4.00 & $12^{\text {th }}$ & 3.91 & $14^{\text {th }}$ \\
\hline 2 & $\begin{array}{l}\text { This firm is a very dynamic and } \\
\text { entrepreneurial place. People are } \\
\text { willing to stick their necks out and } \\
\text { take risks }\end{array}$ & 3.85 & $14^{\text {th }}$ & 4.00 & $11^{\text {th }}$ & 3.78 & $16^{\text {th }}$ & 3.88 & $15^{\text {th }}$ \\
\hline 3 & $\begin{array}{l}\text { This firm is a very result oriented. A } \\
\text { major concern is with getting the } \\
\text { job done. People are very } \\
\text { competitive and achievement } \\
\text { oriented }\end{array}$ & 4.23 & $6^{\text {th }}$ & 4.20 & $4^{\text {th }}$ & 4.12 & $6^{\text {th }}$ & 4.18 & $5^{\text {th }}$ \\
\hline 4 & $\begin{array}{l}\text { This firm is very controlled and } \\
\text { structured place. Formal procedures } \\
\text { generally govern what people do }\end{array}$ & 4.04 & $11^{\text {th }}$ & 4.03 & $10^{\text {th }}$ & 3.94 & $15^{\text {th }}$ & 4.00 & $12^{\text {th }}$ \\
\hline 5 & $\begin{array}{l}\text { The leadership in this firm is } \\
\text { generally considered to exemplify } \\
\text { mentoring, facilitating, or nurturing }\end{array}$ & 4.07 & $9^{\text {th }}$ & 3.96 & $14^{\text {th }}$ & 4.11 & $7^{\text {th }}$ & 4.05 & $10^{\text {th }}$ \\
\hline 6 & $\begin{array}{l}\text { The leadership in this firm is } \\
\text { generally considered to exemplify } \\
\text { entrepreneurship, innovation or risk } \\
\text { taking }\end{array}$ & 3.96 & $12^{\text {th }}$ & 3.99 & $12^{\text {th }}$ & 3.96 & $14^{\text {th }}$ & 3.97 & $13^{\text {th }}$ \\
\hline 7 & $\begin{array}{l}\text { The leadership in this firm is } \\
\text { generally considered to exemplify a } \\
\text { no-nonsense, aggressive, results- } \\
\text { oriented focus }\end{array}$ & 4.29 & $4^{\text {th }}$ & 4.26 & $3^{\text {rd }}$ & 4.30 & $2^{\text {nd }}$ & 4.28 & $2^{\text {nd }}$ \\
\hline 8 & $\begin{array}{l}\text { The leadership in this firm is } \\
\text { generally considered to exemplify } \\
\text { coordinating, organizing, or } \\
\text { smooth-running efficiency }\end{array}$ & 4.24 & $5^{\text {th }}$ & 4.29 & $2^{\text {nd }}$ & 4.21 & $5^{\text {th }}$ & 4.25 & $4^{\text {th }}$ \\
\hline 9 & $\begin{array}{l}\text { The management style in this firm is } \\
\text { characterized by teamwork, } \\
\text { consensus, and participation }\end{array}$ & 4.38 & $1^{\mathrm{st}}$ & 4.07 & $8^{\text {th }}$ & 4.36 & $1^{\mathrm{st}}$ & 4.27 & $3^{\text {rd }}$ \\
\hline 10 & $\begin{array}{l}\text { The management style in this firm is } \\
\text { characterized by individual risk } \\
\text { taking, innovation, freedom and } \\
\text { uniqueness }\end{array}$ & 4.06 & $10^{\text {th }}$ & 4.19 & $5^{\text {th }}$ & 4.22 & $4^{\text {th }}$ & 4.16 & $6^{\text {th }}$ \\
\hline 11 & $\begin{array}{l}\text { The management style in this firm is } \\
\text { characterized by hardworking } \\
\text { competitiveness, high demands and } \\
\text { achievement }\end{array}$ & 4.11 & $8^{\text {th }}$ & 4.15 & $6^{\text {th }}$ & 4.11 & $7^{\text {th }}$ & 4.12 & $7^{\text {th }}$ \\
\hline 12 & $\begin{array}{l}\text { The management style in this firm is } \\
\text { characterized by security of } \\
\text { employment, conformity, } \\
\text { predictability, and stability in } \\
\text { relationships }\end{array}$ & 4.21 & $7^{\text {th }}$ & 4.09 & $7^{\text {th }}$ & 4.04 & $10^{\text {th }}$ & 4.11 & $8^{\text {th }}$ \\
\hline 13 & $\begin{array}{l}\text { The glue that holds this firm } \\
\text { together is the loyalty and mutual } \\
\text { trust. Commitment to this } \\
\text { organization runs high }\end{array}$ & 3.70 & $16^{\text {th }}$ & 3.97 & $13^{\text {th }}$ & 3.97 & $13^{\text {th }}$ & 3.87 & $16^{\text {th }}$ \\
\hline
\end{tabular}


International Journal of Advances in Scientific Research and Engineering (ijasre), Vol 5 (12), December-2019

\begin{tabular}{|c|c|c|c|c|c|c|c|c|c|}
\hline 14 & $\begin{array}{l}\text { The glue that holds this firm } \\
\text { together is commitment to } \\
\text { innovation and development. There } \\
\text { is an emphasis on being on the } \\
\text { cutting edge }\end{array}$ & 4.31 & $2^{\text {nd }}$ & 4.35 & $1^{\mathrm{st}}$ & 4.29 & $3^{\text {rd }}$ & 4.32 & $1^{\mathrm{st}}$ \\
\hline 15 & $\begin{array}{l}\text { The glue that holds this firm } \\
\text { together is the emphasis on } \\
\text { achievement and goal development }\end{array}$ & 3.89 & $13^{\text {th }}$ & 4.07 & $8^{\text {th }}$ & 4.07 & $9^{\text {th }}$ & 4.01 & $11^{\text {th }}$ \\
\hline 16 & $\begin{array}{l}\text { The glue that holds this firm } \\
\text { together is formal rules and policies. } \\
\text { Maintaining a smooth-running } \\
\text { organization is important }\end{array}$ & 4.30 & $3^{\text {rd }}$ & 3.96 & $14^{\text {th }}$ & 4.02 & $11^{\text {th }}$ & 4.09 & $9^{\text {th }}$ \\
\hline
\end{tabular}

\section{CONCLUSION}

The study has explored the concept of organization culture with a view to examine critical factors for constructing organization culture. The study further considered prevalent organizational culture assessment instrument among three large construction companies in Nigeria. There is need for internal cohesion and supportiveness from every member of an organization to maintain a competitive mode of operation in order to achieve an efficient outcome. Furthermore, there is need to focus on factors that tend to positively contribute to the organisations, which should be used for defining the culture of an organisation.

\section{ACKNOWLEDGMENT}

The authors would like to express their appreciation to experts who participated in this research. The information provided was helpful in the conduct of this research.

\section{REFERENCES}

1. R. U. Farooqui, R. Masood, and J. Aziz, “Assessing the viability of total quality management implementation in contracting firms of Pakistan construction industry. Advancing and Integrating Construction Education, Research and Practice. Karachi, Pakistan. 2008

2. B. I. Idrus, and M. Sodangi, "Framework for Evaluating Quality Performance of Contractors in Nigeria". 2010

3. N. A. Ankrah, D. Proverbs, and Y. Debrah, "Factors influencing the culture of a construction project organisation: An empirical investigation". Engineering, Construction and Architectural Management, 2009, 16(1),26-47.

4. R. Violeta, and S. Eleonora, "Factors of Organisational Culture Change". ISSN 1392-1258. 2009

5. S. Aina, F. Adeyeye, and F. Ige, "Organisational Culture and Employees Commitment in Public Tertiary Institutions in Lagos State, Nigeria”. European Journal of Globalization and Development Research, Vol. 3.

6. J. O. Abiola-Falemu, "Impact of organisational culture on organisational business development". Proceedings of the CII-HK Conference 2008, 26 November, TsimShaTsui, Kowloon, Hong Kong, 2008, 99-109. (2)

7. W. A. Bello, A. A. Soyingbe, and M. Akinwami, "An Assessment of the Implementation of Quality Culture in Construction". Las Vegas, Nevada USA. 2008

8. N. Ankrah, and D. Langford, "Architects and Contractors: A comparative study of Organisational Culture". Construction Management and Economics, 23(6), 595 - 607. 2008

9. C. Xiaoming, and H. Junchen, "A Literature Review on Organisational Culture and Corporate Performance". International Journal of Business Administration, 2012, 3(2), 28 - 37.

10. O. O'Donnell, and R. Boyle, "Understanding and Managing Organisational Culture": CPMR Discussion Paper 40. Ireland: Institute of Public Administration in association with The Committee for Public Management Research, 2008

11. I. Abu-Jarad, A. Yusof, and D, Nikbin, "A Review Paper on Organisational Culture and Performance". International Journal of Business and Social Science, 1(3), 26 - 46. 2010

12. R. Rameezdeen, and N. Gunarathna, "Organisational Culture in Construction: An Employee Perspective". Australasian Journal of Construction Economics and Building, 3(1), 19 - 30. 2003

13. E. Schein, "Organisational Culture and Leadership" (Third ed.). San Francisco, CA: Jossey-Bass - John Wiley and Sons, Inc. 2003 
14. E. Oney-Yazici, H. Giritli, G. Topcu-Oraz, and E. Acar, "Organisational culture: the case of the Turkish Construction Industry”. Engineering, Construction and Architectural Management, 14(6), 519 - 531. 2007

15. H. Chilla, Y. Kibet, and M. Douglas, "Effects of Organisational Culture on Organisational Performance in the Hospitality Industry". International Journal of Business and Management Invention, 3(1), 1 - 13. 2014

16. J. Abiola-Falemu, D. Ogunsemi, and O. Oyediran, "Assessment of organisational culture and innovation practices of construction companies in Southwest Nigeria". In P. Barret et al (Ed.), TG59 and W112- Special Track 18th CIB World Building Congress CIB task Group and Working Commission.(pp. 218 - 233). 2010

17. E. McKenna, and N. Beech, "Human Resource Management: a concise analysis". Harlow, England: Pearson Education Limited. 2000

18. R. Fellows, and A. Liu, "Use and misuse of the concept of culture". Construction Management and Economics, 31(5), 401 422. 2013

19. I. Abu-Jarad, A. Yusof, and D. Nikbin, “A Review Paper on Organisational Culture and Performance”. International Journal of Business and Social Science, 1(3), 26 - 46. 2010

20. D. Campbell, G. Stonehouse, and B. Houston, "Business Strategy: An introduction" (Second ed.). Oxford: ButterworthHeinemann. 2002

21. F. Abdul Nifa, and V. Ahmed, "The role of organisational culture in construction partnering to produce innovation" in C. Egbu (Ed.), procs 26th Annual ARCOM Conference Leeds, UK: Association of Researchers in Construction Management. 2010, (pp. 725 - 734).

22. O. Adewale, and A. Anthonia, "Impact of Organisational Culture on Human Resource Practices: A Study of Selected Nigerian Private Universities”. Journal of Competitiveness, 2013, 5(4), 115 - 133.

23. A. Bernard-Tuffour, "Organisational Culture in the Ghanaian Construction Industry" .https://www.researchgate.net/publication/308786377. Accessed16/10/2019

24. Bath Consultancy Group, (2006). Culture Analysis, Retrieved September 27, 2006, from http://www.bathconsultancygroup.com/.Author. (2)

25. H. Abdul-Rahman, W. Chen M. S. Mohd-Danuri, and F. A. Mohd Rahim, "Subsequent survey on project management using cultural factors in the Malaysian construction industry", Proceedings of Quantity Surveying National Convention, 4-5 September, Malaysia, 2006, 178-184. (2)

26. P. Hoonakker, "Quality Management in Construction Industry". Center for Quality and Productivity Improvement (CQPI).(Accessed 14/9/2019).

27. B. M. Tharp, "Four Organisational Culture Types". Haworth Organisational culture white paper, 2009. 1-6. TQM. www.johnstark.com.

28. L. Harvey, and B. Stensaker, "Quality Culture: Understandings, Boundaries and Linkages". European Journal of Education, 2008, 43(4), 1-18.

29. W. Y. Mahmood, W. Mohammed, M. S. Misnan, Z. M. Yusof, and A. Bakri, "Development of Quality Culture in the Construction Industry”. In ICCI 2006, pg1-11. Beijing. International Journal of Civil and Environmental Engineering, 10 (1), 34-39.

30. M. Sodangi, A. Idrus, and F.M. Khamidi, "Measuring Quality Performance in Construction”. 2010

31. L. S. Pheng, and J, A. Teo, "Implementing Total Quality Management in Construction Firms", Journal of Management in Engineering, 2004, 20(1), 8-17 